\title{
Motivation, Attitude, Role Of Drug Control (Pmo) With Drug Compliance In Patients Tb
}

\author{
Marniati ${ }^{1}$, Nurlina ${ }^{2}$, Safruddin ${ }^{3}$ \\ S1 Nursing Study Program, Stikes Panrita Husada Bulukumba, Indonesia1 \\ Departemen Mental Health Nursing , Stikes Panrita Husada Bulukumba ,Indonesia ${ }^{2}$ \\ Departemen Community and Family Nursing , Stikes Panrita Husada Bulukumba, Indonesia ${ }^{3}$
}

Corresponding Autor : nurlinapanrita@gmail.com

\begin{abstract}
ABSTRAK
Pulmonary tuberculosis is a direct infectious disease caused by TB (Mycobacterium Tuberculosis) bacteria. The level of compliance with the use of pulmonary TB drugs is very important and requires a long time that is 6-8 months, because if treatment is not carried out regularly or is not compliant and does not correspond to the specified time then there will be resistance (resistance) of tuberculosis germs against drugs Widespread Anti Tuberculosis (OAT) or Multi Drugs Resistance (MDR). The purpose of this study was to determine the relationship between motivation, attitudes, the role of supervisors taking medication (PMO) in TB sufferers. The design of the study used an Analytical Observational design using the CrossSectional approach. The population in this study were all TB sufferers in Bulukumba District with a sampling technique using cluster sampling. The number of samples in this study were 60 respondents. Data were obtained through questionnaire sheets made by researchers to respondents. Data analysis used Fisher's alternative Chi-square Test, with significance level $\alpha=$ 0.05 . The results of the data analysis show that the motivation variable $p=0.023$, the attitude variable $p=0.012$, and the role of the supervisor for taking medication (PMO) $p=0.017$. So it can be concluded that there is a relationship between motivation, attitude, the role of supervisors taking medication (PMO) with adherence to taking medication in TB patients in Bulukumba Regency.
\end{abstract}

Keywords: Motivation, Attitude, Role of Drug Drinking Supervisors (PM0), Drug Compliance.

\section{INTRODUCTION}

Pulmonary tuberculosis is a direct infectious disease caused by TB (Mycobacterium Tuberculosis) bacteria. The main symptoms are cough for 2 weeks or more, cough is accompanied by additional symptoms that are phlegm, phlegm mixed with blood, shortness of breath, body weakness, decreased appetite, weight loss, malaise, night sweats without physical activity, fever for more than 1 month (Riskesda, 2013).

World Health Organization (WHO) 2014, explained the data in 2013 estimated that 9.0 million people (around 8,600,000-9,400,000) suffered from tuberculosis and 1.5 million died from tuberculosis. The three countries that had the largest number of cases in 2013 were India (2.0 million-2.3 million), China (0.9 million-1.1 million), Nigeria $(340,000-880,000)$. Indonesia is a country ranked fifth with tuberculosis cases with a 
number of cases (410,000-520,000). Of the 9.0 million incident cases, an estimated 550,000 occur in children and 3.3 million (range 3,200,000-3,500,000) occur among women. According to Riskesda (2013) the prevalence of Indonesian population diagnosed with pulmonary TB in 2013 was $0.4 \%$. The five provinces with the highest pulmonary TB are West Java (0.7\%), Papua (0.6\%), DKI Jakarta (0.6\%), Gorontalo (0.5\%), Banten (0.4\%), West Papua ( 0.4\%), and in South Sulawesi (0.3\%) (Riskesda, 2013).

In South Sulawesi, the number of pulmonary TB per regency / city in 2015 the number of TB cases was 12,625 . The amount of BTA + was 8,348 people, with 7,008 (73.36\%) recovery. The BTA + treated 8,943 people, 5,363 men and 3,580 people, the number of TB children 0-14 years was 581 people (4.60\%), complete treatment of 680 people (7.60\%), 429 men and 251 women, with a success rate of $85.97 \%$ ie $84.58 \%$ men and $88.04 \%$ women. The number of pulmonary TB sufferers per regency / city in South Sulawesi in 2016 was 13031 people, pulmonary TB patients who ranked first were Makassar as many as 3916 people, Gowa as many as 1339 people, Wajo as many as 810 people, Bone as many as 655 people, Pangkep as many as 590 people , Sidrap as many as 568 people and in Bulukumba district as many as 507 people. (Health Profile of South Sulawesi Province, 2017).

Data from Bulukumba Regency shows that the number of pulmonary TB sufferers has increased from year to year. In 2014 there were 108 people and increased in 2016 by 194 people. Pulmonary TB sufferers who rank first in the Bonto Bangun Health Center as many as 37 people, followed by caile Health Center as many as 33 people and Gattareng Health Center as many as 29 people (Dukes of Bulukumba District Health Office, 2016). Based on interviews with one of the fields of TB in the Bulukumba Health Service said that one of the main problems in pulmonary TB disease is drug resistance or drug resistance caused by lack of family support, lazy taking medication, length of treatment, and non-compliance with treatment. So it requires a very long time to consume the drug that is 20 months with high drug doses. According to Paterson and Plowman (in Hasibuan, 2008), which said that the motivating factor for one's motivation is the desire to live. The desire to live is the main desire of every person, humans work to be able to eat and eat to continue his life. The higher the motivation of someone to achieve something, the higher the effort spent for the desired goal. Lack of 
motivation or desire to recover will cause non-compliance to seek treatment regularly so that it will become an obstacle to achieving a high cure rate (Nurwidji \& Fajri, 2013).

According to research conducted by (Nurwidji \& Fajri, 2013) namely the title of the relationship of healing motivation with treatment management in pulmonary TB patients in the working area of Mojosari Mojokerto Puskesmas. The results of his research that most respondents have a strong motivation that is $67 \%$. In this study, respondents who have a strong healing motivation, most of them are respondents who have a desire to live and a high desire to recover. So that will increase one's motivation to recover from his illness. Attitude is an order between components of thought (cognitive), feeling (affective), and predisposing actions (conative) that interact with each other in understanding, feeling, and behaving towards an object in the surrounding environment (Dhewi, Armiyati, \& Supriyono, 2011).

According to research conducted (Dhewi, Armiyati, \& Supriyono, 2011) namely with the title research Relationship Knowledge, Patient Attitudes and Family Support with Compliance with Taking Medication in Pulmonary TB Patients in BKPM PATI. The sample in this study were 40 people. The results of the analysis showed that the attitude of pulmonary TB respondents in the treatment of pulmonary TB included in the good category of taking medicine as many as 31 respondents (77.5\%), the family support of respondents in the treatment of pulmonary TB included in the good category of 29 respondents (72.5\%), and patients with insufficient knowledge, have the opportunity to not comply with medication 3,857 times. The results showed a significant relationship between knowledge, attitude and family support with medication adherence.

The Role of Drugs Supervisors (PMO) plays an important role in enhancing medication adherence. Family attention and support in supervising and reminding sufferers to take medicine can improve health status (Dhewi, Armiyati, \& Supriyono, 2011).

According to research conducted by Jufrizal, Hermansyah, and Mulyadi (2016) namely under the title research Role of the family as supervisors taking medication (PMO) with the success rate of treatment of patients with pulmonary tuberculosis. The population in this study were 63 families who had pulmonary TB sufferers. The results showed the role of the family as PMO in both categories (79.4\%) and the success rate of treatment (73\%). Then it can be concluded that there is a relationship between the role 
of the family as the Superintendent of Taking Medication (PMO) with the success rate of treatment of patients with pulmonary tuberculosis.

The level of compliance with the use of pulmonary TB drugs is very important, and requires a long time that is 6-8 months, because if treatment is not carried out regularly or is not compliant and does not correspond to the specified time then there will be resistance (resistance) of tuberculosis germs against drugs Widespread Anti Tuberculosis (OAT) or Multi Drugs Resistence (MDR). In the end incur high and expensive costs and relatively long time (Pameswari, Halim, \& Yustika, 2016). The purpose of this study was to determine the relationship of motivation, attitudes, the role of supervisors taking medication (PMO) with adherence to taking medication in $\mathrm{TB}$ patients in Bulukumba Regency in 2018.

\section{MATERIAL AND METHODS}

This type of research is a quantitative study using an Analytical Observational design using the Cross Sectional approach (Hidayat, 2014), which aims to determine the relationship of motivation, attitudes, warfare drug users (PMO) with adherence to taking medication in tuberculosis sufferers in Bulukumba Regency. Population is a generalization area that consists of objects / subjects that have certain quantities and characteristics determined by researchers to be studied and then drawn conclusions (Sugiyono, 2012). The population in this study were all TB patients who were treated in Bulukumba District including the working area of the Bonto Bangun Health Center, Caile Health Center, Gattareng Health Center and Ponre Health Center. Sampling in this study using Probability Sampling with the Cluster Sampling method, the sampling technique used if the object to be studied is very broad (Setiadi, 2013). The number of samples in this study were 60 TB patients.

The instrument in this study was a questionnaire (questionnaire). The questionnaire was used to collect data on motivation, attitudes, the role of supervisors taking medication, and medication adherence. Data were analyzed based on measuring scale and research objectives using computerized program software. Data were analyzed by: (1). Univariate Analysis, Analysis is done to see the proportion. (2). Bivariate Analysis, Bivariate test is carried out to find the relationship between the independent variable and the dependent variable with the test used is chi-square when 
it meets the requirements, and fisher's exact test will be conducted as an alternative. Significance is accepted if $\mathrm{p}<0.05$.

\section{RESULTS}

Based on (Table 1) shows the majority of respondents male sex as many as 32 people (53.3\%), most of the age of the respondents are in the elderly category as many as 26 people (43.4\%), the majority of respondents with basic education amounted to 39 people (65.0\%), the majority of respondents not working were 32 people (53.3\%).

Table 1. Frequency Distribution Based on Respondent Characteristics

\begin{tabular}{|c|c|c|}
\hline Characteristics & $\mathrm{N}$ & Percentage (\%) \\
\hline \multicolumn{3}{|l|}{ Gender } \\
\hline Male & 32 & 53,3 \\
\hline Female & 28 & 46,7 \\
\hline \multicolumn{3}{|l|}{ Age } \\
\hline Teenager & 5 & 8,3 \\
\hline Adult & 25 & 41,7 \\
\hline Elderly & 26 & 43,4 \\
\hline Old man & 4 & 6,7 \\
\hline \multicolumn{3}{|l|}{ Last education } \\
\hline Basic & 39 & 65,0 \\
\hline Intermediate & 21 & 35,0 \\
\hline \multicolumn{3}{|l|}{ Profession } \\
\hline Work & 28 & 46,7 \\
\hline Does not work & 32 & 53,3 \\
\hline Amount & 60 & 100,0 \\
\hline
\end{tabular}

Based on (Table 2) shows the frequency distribution of respondents based on motivation, attitudes, the role of supervisors taking medication (PMO) with adherence to taking medication in TB patients.

The frequency distribution of motivation mostly has high motivation as many as 46 people (76.7\%), while at least the respondents who have low motivation are 14 people (23.3\%). Most respondents have good attitudes as many as 48 people (80.0\%), while at least the respondents who have bad attitudes as many as 12 people (20.0\%). The role of supervisors taking medication Most of the respondents have the role of supervisors 39 people taking good medicine (65.0\%), while the most respondents who had the role of supervisors taking medication were not good 21 people (35.0\%). And the majority of obedience to take medication was 54 people (90.0\%), while at least 6 respondents (10.0\%) did not comply. 
Table 2. Frequency distribution of the number of respondents based on motivation, attitude, role of supervisors taking medication with medication compliance

\begin{tabular}{lcc}
\hline \multicolumn{1}{c}{ Variable } & N & (Percentage (\%) \\
\hline Motivation & 46 & 76,7 \\
High & 14 & 23,3 \\
Low & & \\
Attitude & 48 & 80,0 \\
Well & 12 & 20,0 \\
Not good & & \\
The role of the PMO & 39 & 35,0 \\
Well & 21 & \\
Not good & & 95,0 \\
Compliance with Medication & 54 & 90,0 \\
Obedient & 6 & 10,0 \\
Not obey & 60 & 100 \\
\hline Amount & & \\
\hline
\end{tabular}

Based on (Table 3) shows the relationship of motivation with medication adherence where respondents who have high motivation are more obedient to take medication as many as 44 people (95.7\%) are greater than those who have low motivation as many as 10 people (71.4\%). So as a percentage it can be concluded that there is a difference in the proportion between motivation and medication adherence. Chi-Square alternative Fisher's test results obtained $\mathrm{p}=0.023(\mathrm{p}<0.05)$, then concluded that there is a significant relationship between motivation with medication adherence. The relationship of attitude to taking medication where respondents who have a better attitude to take medication as many as 46 people (95.8\%) is greater than the respondents who have an attitude of less than 8 people (66.7\%). Thus, the percentage can be concluded that there is a difference between attitude and drinking. Fisher's alternative Chi-Square test results obtained $\mathrm{p}=0.012(\mathrm{p}<0.05)$, then concluded what is related to the relationship between taking drugs.

The relationship between the role of supervisors taking medication with adherence to take medication where respondents who have a good PMO role are more obedient to take medicine 38 people (97.4\%) is greater than respondents who have an unfavorable PMO role of 16 people (76.2\%). So as a percentage it can be concluded that there are differences in the proportion between the role of PMOs with medication adherence. Fisher's Chi-Square test results obtained $\mathrm{p}$ value $=0.017(\mathrm{p}<0.05)$, it was concluded that there was a significant relationship between the role of supervisors taking medication with medication adherence. 
Table 3. Relationship of motivation, attitude, and approval of taking medication with drinking drugs in TB patients in Bulukumba Regency

\begin{tabular}{|c|c|c|c|c|c|c|}
\hline \multirow{3}{*}{ Motivation } & \multicolumn{4}{|c|}{ Compliance with Taking Medication } & \multirow[t]{3}{*}{ Amount } & \multirow{3}{*}{$P$} \\
\hline & \multicolumn{2}{|c|}{ Obedient } & \multicolumn{2}{|c|}{ Not Obedient } & & \\
\hline & $\mathbf{N}$ & $\%$ & $\mathbf{N}$ & $\%$ & & \\
\hline High & 44 & 95,7 & 2 & 4,3 & 46 & \\
\hline Low & 10 & 71,4 & 4 & 28,6 & 14 & 0,023 \\
\hline Attitude & $\mathbf{N}$ & $\%$ & $\mathbf{N}$ & $\%$ & & \\
\hline Well & 46 & 95,8 & 2 & 4,2 & 48 & \\
\hline Not good & 8 & 66,7 & 4 & 33,3 & 12 & 0,012 \\
\hline The role of the PMO & $\mathbf{N}$ & $\%$ & $\mathbf{N}$ & $\%$ & & \\
\hline Well & 38 & 97,4 & 1 & 2,6 & 56 & 0017 \\
\hline Not good & 16 & 76,2 & 5 & 23,8 & 4 & 0,017 \\
\hline Amount & 54 & & 6 & & 0 & \\
\hline
\end{tabular}

\section{DISCUSSION}

In this study it was seen that there was a significant relationship between motivation, attitude, the role of supervisors taking medication with adherence to taking medication in TB patients in Bulukumba.

From the results of the Chi-Square alternative Fisher test obtained $\mathrm{p}$ value $=0.023$ ( $p$ <0.05), it was concluded that there was a significant relationship between motivation with medication adherence. This is in line with the results of the study (Muhardiani, Mardjan, \& Abrori, 2015) motivation with the process of medication adherence to pulmonary TB sufferers in the work area of healthy gang health centers with a value of $\mathrm{p}=0.009$.

The researchers' assumptions are related to the results of the study that found that the number of respondents who have high motivation more than low motivation. This happens because the desire of the respondent to recover is greater and there is also support from the family so that the respondent remains enthusiastic in undergoing treatment. However, there are still respondents who have high motivation who are not compliant to take medicine. This is because the patient is only motivated by himself to recover from his illness without the support given by his family. And there are still respondents who have low motivation but are obedient to take medicine, in this case the education of respondents which is mostly secondary education that can influence the results of research. 
From the Chi-Square alternative Fisher's test results obtained $\mathrm{p}=0.012(\mathrm{p}<0.05)$, then it was concluded that there was a significant relationship between attitude and medication adherence. This is in line with research (Maulidya, Redjeki, \& Fanami, 2016) the attitude of patients with the success of pulmonary TB treatment at Dinoyo Community Health Center with a value of $\mathrm{p}=0.008$.

The researchers' assumptions are related to the results of the study that found the number of respondents who have a good attitude more than those who have a less good attitude. This happened because respondents are able to accept the disease they are experiencing and agree to a treatment that requires a long time that is 6-8 months. However, there are still respondents who have a good attitude but are not compliant to take medicine. This happened because the respondent was busy with his work as a farmer or there were other activities so that the respondent forgot to take medicine and there was no reminder. And there are still respondents whose attitude is not good but obedient to take medicine, this happens because respondents have high motivation to recover from their illness. Wherever the patient goes or does activities, the patient always brings the medicine and there is also encouragement from the closest people such as family who support the respondent's treatment so he is obedient to take medicine.

From the Chi-Square alternative Fisher's test results obtained $\mathrm{p}$ value $=0.017(\mathrm{p}$ $<0.05$ ), then it was concluded that there was a significant relationship between the role of supervisors taking medication with medication adherence. This is in line with the results of the study (Ratna, 2014) the relationship between the role of supervisors taking medication with medication adherence with a value of $\mathrm{p}=0.033$.

The researcher's assumption is related to the results of the study that found the number of respondents the role of supervisors taking good medicine more than the less good. This happens because supervisors take medicine from health workers or their families actually carry out their role or convince respondents to always take medication regularly, able to explain the causes, symptoms, benefits of treatment, stages of treatment, how to spread TB and what are the side effects from the drug. However, there is still the role of the supervisor to take good medicine which is not compliant to take medicine. This happens because the patient feels a reaction from the drug such as feeling dizzy, aching muscles and joints, nausea and vomiting, so the patient is not compliant to take medication. And there is still the role of supervisors taking medication 
that is not good but obedient to take medicine, this happens because the respondent has a strong motivation in him to seek treatment so that he can recover quickly from his illnes.

\section{CONCLUSION}

Based on the results of the study above, it was concluded that there was a significant relationship between motivation, attitude, the role of supervisors taking medication with adherence to taking medication in TB patients in Bulukumba Regency. The results of this study are expected to provide information and can be used as a guide to continue to provide health promotion and improve work programs related to pulmonary TB that can be used to further increase public knowledge and awareness. And it is also important to explain the reaction or side effects of the drug to TB sufferers before being given treatment. For future researchers, the results of this study can be used as data or basic information to carry out further research using a different methodology. To obtain more in-depth results, qualitative research methods can be used, for example to examine more closely the attitude that tends to be negative. For quantitative research with a larger sample size.

\section{REFERENCES}

Dhewi, G. I., Armiyati, Y., \& Supriyono, M. (2011). Hubungan antara Pengetahuan, Sikap Pasien dan Dukungan Keluarga dengan Kepatuhan Minum Obat pada Pasien TB Paru Di BKPM PATI.

Dinkes Kab Bulukumba. (2016). Profil Dinas Kesehatan Kab Bulukumba.

Hidayat, A. A. (2014). Metodologi Penelitian Keperawatan dan Teknik Analisis Data. Jakarta: Salemba Medika.

Jufrizal, Hermansyah, \& Mulyadi. (2016). Peran Keluarga Sebagai Pengawas Minum Obat (PMO) dengan Tingkat Keberhasilan Pengobatan Penderita Tuberkulosis Paru . Jurnal Ilmu Keperawatan.

Maulidya, Y. N., Redjeki, E. S., \& Fanami, E. (2016). Faktor yang Mempengaruhi Keberhasilan Pengobatan Tuberkulosis (TB) Paru Pada Pasien Pasca Pengobatan di Puskesmas Dinoyo Kota Malang. Jurnal Kesehatan.

Muhardiani, Mardjan, \& Abrori. (2015). Hubungan Antara Dukungan Keluarga, Motivasi, dan Stigma Lingkungan dengan Proses Kepatuhan Berobat Terhadap Penderita TB Paru di Wilayah Kerja Puskesmas Gang Sehat. Jurnal Mahasiswa dan Peneliti Kesehatan-Jumantik. 
Muna, L., \& Soleha, U. (2014). Motivasi dan Dukungan Sosial Keluarga Mempengaruhi Kepatuhan Berobat pada Pasien TB Paru di Poli Paru BP4 Pamekasan. Jurnal Ilmiah Kesehatan .

Nurwidji, \& Fajri, T. (2013). Hubungan Motivasi Kesembuhan dengan Kepatuhan Penatalksanaan pengobatan pada Pasien TB Paru di Wilayah Kerja Puskesmas Mojosari Mojokerto. Medica Majapahit.

Profil Kesehatan Provinsi Sulsel. (2017). Profil Dinas Kesehatan Provinsi Sulsel.

Ratna, R. D. (2014). Hubungan antara Peran Pengawas Minum Obat (PMO) dengan Kepatuhan Kunjungan Berobat pada Pasien Tuberculosis Paru (TB Paru) di Puskesmas Nogosari Boyolali. Jurnal Kesehatan.

Riskesda. (2013). Prevalensi TB Paru berdasarkan diagnosis dan gejala TB Paru menurut provinsi, Indonesia 2013.

Riskesda. (2013). Tuberkulosis Paru (TB Paru).

Setiadi. (2013). Konsep Dan Praktik Penulisan Riset Keperawatan. Yogyakarta: Graha Ilmu.

Sugiyono. (2012). Metode Penelitian Kuantitatif Kualitatif dan R\&D. Bandung: Alfabeta. 